should then be darkened, and the utmost possible quietude should be maintained. It is offen cxtremely ndvantareous, cspecia!ly in cases of melaneliolia, to give a glass of egg-nogg or a generous dose of malt estract at bedtime, or a cup of hot ehocolatc, and in the milder cases or in the convalescent stagc a light supper may be combiacd with these.

Tonies and alteratives may be adininistered in these curable forms of insanity, according to the rules obtaining in general medieine. Quinine, cod-liver oil, and the malt extracts nre most useful. Phosphorus is oecasionally a most exeellent tonic in the lnter periods of eonvalescenee, and should be given in the formula first proposed by Ashburton Thomp. Eon.' Galvanization of the eercbrum and the spiunal cord is an invaluable aid in the treatment, especially in the cervieal and oecipital neuralgias that are so apt to follow nttaeks of melancholia. Galvanization of the cercbrum should be very earcfully done, one large eleetrode (about four to five inches) being placed upon the forehend, another of equal sizc upon the oeeiput, and $n$ gentle current of three to five milliamperes passed for a period varying from two to five minutes. Great carc should be taken to nvoid any interruption in the current. Galvanization of the spinal eord slould be done by neans of eleetrodes, of the size just mentioned, upon the upper eervieal and lower dorsal eord respeetively, but a mueh larger current should be employed, ranging from five to fifteen to trienty milliamperes, and the sitting lasting frow five to fifteen minutes. General famdization is nlso often of great use. In some cases the cleetrie brceze from $n$ static or Holtz maeline is estremely bencfieial to the paticnt.

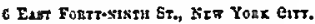

\title{
PULSATING PLEURISY.:
}

\author{
By Williay Oslen, M.D.

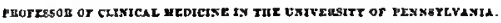

Pulsatisg pleurisy is such a rare condition that the following case is worth plaeing upon record:

Strain in lifting: pain in left side; rapid effuzion, at first serous, necessitating two aspirations; pyo-pneumothorax; pulsation of side; free drainage; recovery.-James F., aged twenty-three years, laborer, was admitted to the University Hospital Mnreh 3, 1888. Family history

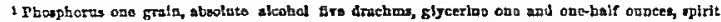
of wine two drachme, opirit of peppermint two scruples; divolro tho phoaphoru ln the alcohol with

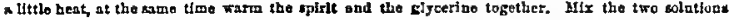
whllo bot, and add tho spirit of peppermint on coollng. Doso nno-hail a drechor to two drachms.

a Read by titlo at the meeting of the Ansociation of American Pbysiclans, Wianington, 188. 
good; none of his relntives have had phtlisis; with the exeeption of . an attack of rlumatism in 1885 , he has enjosed uuiformly good health.

On February the $23 d$, eight dnys before admission, he spraiued his baek by lifting a piece of timler twenty feet in length and ten inehes in diauter. Three men mere lifting it, lut one of them let go his loold so that the patient had to exert his utmost strength to support his end of the piece. At the time lie did not feel any diseomfort, lut that evening be beeane sore and stiff. He slept well, and the next dny, a pullic boliday, he went ahout with his eomrades, lut eomplained on sereral oecasions that lie lad spruined his haek with heary lifting. During the ereniug the pain grew worse and he passed a restless niglit. The fillowing morning be did not feel well enough to get up and the pain had beeome alnost unliearable. There was no cough or shortncss of breatli ; be does not know whether he had auy fever.

From the 26 th to the $3 d$, the date of his admission, lie was " up and down;" in bed part of the time, and part of the time lyy the kitehen fire. The pain in the back was his only complaint. $\mathrm{He}$ is positive he had no eough, but he was short of lirenth.

On adinission, the patient looked very ill; face flushed, tongue dry and coated; respirations 36 , temperature $100^{\circ}$. He was ahlo to he down iu hed. The importance attnched to the lifting on Fehrunry $23 \mathrm{~d}$ may be gatleered from the fuet that he was admitted to tle surgical ward as a case of injury to the back, and sulisequently transferred. The day afer udmissiou he had much pain, of a eutting nature, in the left side, ju the axillary regioa outside the nipple. There whs also extrene tenderness on palpatiou.

- I saw the patient for the first time on Murcli 5th, aud was struek with his distressed appearanee. He lay propped up in hed, had slight dyspnas, dry tougrie, pulse 100 , temperature $100^{\circ}$. He complained of serere pain in the left back, just lielow the seapula. On examination the existen ce of a large effusion in the left pleura was readily determiaed. The enrdine impulse was in the third right interspace is the para-steran line. I notieed one or two speeisl features in the cuse : the sudden onset afcer the strain, tlie renarkable rapidity with which the effusion had taken place, and the unusual amonnt of pain on palpation.

Marcl 6tl, a more thorough examiaution was unde: expansion was almost negative on the left side; the iutereostal spaces indistinguishahle. The only eardiac impulse visilile was in the third rirht interspee. Taetile fremitus was dininished. There was uniform duluess on the left eide reuching to the elaviele and extending a little heyond the riglat margin of the sternum in the second interspace. By n lypodernie puneture the fluid was sllow to be serous. On the prineiple that a full pleura demands immediate aspiration this operation was performed ly Dr. Daland before the ward elass, and fifty ounes of elear serum remored.

On the 5 th ind $6 \mathrm{th}$, the patient seemed mueh relieved. By the 9 th the fluid lad reaceumulated and the heart beat was arain visible to the right of the stermm, the dulness reaching to the level of the elaviele. Aspiration was again performed nud two qunrts of slightly turlid serum removed. He seemed to inprove very much after this. The tempera. ture kept lielow $99^{\circ}$, the dyspnoen was relieved, the appetite improred, nnd with the exeeption of pain in the left side he felt very comfortable. The signs of effusion persisted and the heart beat could be seen in the third left aud the third right interspaces. 
16th. The followiag note was made: Condition of patient has im. proved, pulse 84 , respiration 28 , temperature $98^{\circ}$; dyspncen seems quite relieved, sleeps with his hend law, complains only of chest pain; left side scarcely moves, and looks somewhat hulged. Cardinc impulse seen in the second and third spnees on hoth sides close to the sternum. The left interspaces not specinlly prominent. Tactile fremitus felt at the extreme apex, but nowhere else on the left side; percussion note clear to the second rib, dull below this. On the right side normal.

Auscultation: Inspiration is laud and hreezy in the subclavicular and supra-scapular regioas. Belaw these points the respiratory murmur bas a distinctly amphoric charaeter, eontrasting remarkably with the breath sounds over the upper part af the lung. The voice sounds in the lower regions are very articulate; no metallic tinkling on coughing. No hell sound, nor could succussion be obtained.

19th. To-day for the first time it was observed that the percussion note in the left subclavieulnr region was distinctly tympanitic. Dulness extended from the upper horder of the third rib, and was distinetly movable. This was very marked when he lay on his right side, in whieh position the pereussion note in the nxilla became hyper-resonant without tympanitie quality. Posteriorly in ereet position at outer angle of the scapula the pereussion note was distinetly tympanitie. To-day, for the first tims, the hell sound was obtained with the eoins.

¿6th. Since the 20 th he has had irregular fever renehiug $102^{\circ}$ in the evening. He has, lowever, felt much better. The physical signs persist; in the recumbent posture the note is hyper-resonant to the lower border of the third rib. Just helow the nipple it is distinctly tympanitic, from this point into the axilla there is dulness. When he turns on bis right side the entire left axilla is resonant. There is amphorie breathing fron the third rih, hest marked in the lower axilla, where the pereussion note is dull. There was notieed ta-day in the fourth, fifth, and sisth interspaees in the nid-axillary line a remurkable pulsation. The whole side reeeived a very positive shoek, systolie in time and synehronous with the eardiae impulse in the third right interspace just nhove the nipple; the hand placed on the left side is distinetly lifted with eneh inpulse. When he lies toward the right side the pulsation in the left axilla is a little more marked thisn when le is flat an his haek.

ofth. The common decubitus is an the left side and in this position the heart impulse is well secn just above the right nipple. The pulsation in the left mnmmary aud nxillary regions is very marked. The maximum intensity is outside the left nipple. Wlien he turns on the right eide the pulsation is most marked in the fiftl and sistl interspaces in the mid-axillary linc. Palpation gives a very decided heave and a distinet shock is felt. In the ercet posture, the pulsation is a ot so foreible, thougl still very evident. The coin sounds are now unusually distinct. Succussion is not obtainable.

29th. The left chest looks larger and fuller than the right ; it is com. pletely immobilc. The intereostal spaces nre ohliterated with the exception of the sixth, which is still visible. The systolic impulse on the left side is very marked, and ean readily he seen by the students in the distant seats of the a mphitheatre- Mensu rement on the right side gives sixteen and one-eighth inches, expansian ane-half inch; on the left side, seventeen and one-quarter inches, praetically no expaosion. 
Palpation.-Tactile fremitus is absent on the left side. Heaviug impulse in the mammary and nxillary regions well felt with the hand.

Percussion.-Clear, hyper-resonnnt note to upper borler of the third rib. From the third to the fifth it is distinetly tympanitie. Below this, in the axillary region there is dulnes. When he turns on his right side the pulsution in the manmary nud axillary regions is inore marked. Where the percussion note was dull, it is now tympanitie.

Aucullation.- In the left infra-elnvieular region the breath sounds are loud and listinet, not amphorie. In the third and fourth interspaees the respiratory murmur is searcely audible. In the axillary regions there is distant but distinct anphorie breathing, very clearly heard when $\mathrm{n}$ deep brenth is taken. No speeial amphorie eeho about the voice, the vibrntinns of which nre not eommunieated to the ear; posteriorly there is distant amphorie breatlinig.

S1st. The irregular fever has persisted ind the presence of pus was demonstrated with a hypodernic needle. It was decided to open tho pleura, whicls was done hy Dr. Ashlurst; fully three pints of pus esenped. A harge drainage tube was imserted in the eighth interspuce below the augle of the scapula. After the operation, the heart did not return to its normal position, though it beat to the left of the sternmm. Patient stood the operation very well, the evening temperature was only 98.2

April s. Pulse 92, respiration 24, temperature 98\%. Inspeetion showed a remarkable elutige on the lelt side of the ehest; it alrealy looks smuller than the riglit, and there is fiattening in the second, third, fourth, and lifth intercostal spaecs; there is very marked pulmonary resonance to fourth rib. Tympanitic in the fifh, sixtl, and seventh intersptees.

With the exeeption of the lifth, when the temperature rose in the erening to $102^{3}$, the patient's condition was most satisthetory. He slept Irell, uppetite good, temperature did not rise above $99^{2}$; there was free drainage through tube.

14 th. Chest measured to-day: right side, fifteen and a half inelies; left, hifteen and one-eightl. Diseluarge very light. From this time the patieat improved very rapily ; temperature lins not risen above $100^{\circ}$.

1Fay 9 . The discharge is now slight. A smiller drainage tube was introdueed; the discharge gradually dininished, and he improved rapidly in strengtl and weight. Early in June the tube was removed.

June 10. The note is that the sinus has entirely healed. He left the hospit:ll on the 15 th, weighing 140 pounds, a giain of twenty-two pounds since $A$ pril 1fth.

The condition of his eliest on discharge was as follows: There was marked finttening of the left side, partieularly in the nxillary and mam. mary rerions. The eireumference was: right, fifteen and three-quarters; left, fiftem :nd one-quarter inches. The percussion note was clear to the fifth rib and the spine ol the seapula behind, below these points there was dulness. Loud breath sounds in the clavicular and mammary regions, feeble and distunt in lower axilinry, and at base.

I believe that this was an instnnce of pmeumothorax froa the outset, one of those interesting cases to whieh Dr. Samuel West ${ }^{t}$ and Dr. de Harilland Hall' have called nttention, in which the condition has fol- 
lowed strain in a persoa previously healthy. - It is very improbable that on the eighth day of an aeute pleurisy there would be a serous exudntion of such exteat as to reach the elavicle and encroach on the plenra of the other side. On the other hand, the pereussion note, as is well known, may be dull ia pneunothorax wben the tension of the thoracie wall is very great, and I think that in this way the nistake arose. The mode of onset in a lealthy man, the course of the disense, and the rapid and complete recovery fuvor the view that the straiu had induced a pneunothoras whieh excited the pleurisy.

The ehief iaterest of the case lies, however, in the curious pheaomenon which developed in the fifth week after the attack.

Instances of tumors of the thoracie wall, which pulsated syuehronously with the heart, are mentioned by several of the older writers-Buillon (1640), Le IR(y (1776), and Pelletan (1810)-but the first cases of pulsating enpyeraa, recogaized as sueh, were reported by the late Dr. $R$. L. Mraedonnell, ${ }_{3}^{1}$ Professor of Clinicul Medicjue in McGill University, Montreal, who, at the time, was elinical nssistant to Drs. Graves and Stokes, at the Meatlı Hospital, Duhlin.

In the first of these eases a large tunior appeared in the cardinc region, whicl, after pulsating for some time, became red, tense, aud shiniag, and then hurst, giviug exit to a large quantity of pus.

Iu the seeond case two tumors appeared in the lower part of the left side, presenting fluctustion and pulsation. Whea opeaed puralent matter eseuped in large quautities.

In the third euse two large tumors appeared in the lower portion of the left sile of the chest, presenting fluetuation and pulsation. They were openod and discharged a large quantity of pus. Death followed in all these extes.

Dr. Mnedonnell remarked that this eondition was new in the bistory of empyema.

Several eareful studies of pulsating pleurisy have recently heen made. One by Conby," who eollected 27 cases; and a second hy Kepler, who has collected 38 case autloors-Drs. Flint ${ }^{4}$ and Dillinghanl, from the rards of $\mathrm{Dr}$. J. H. Ripley at St. Francis Hospital, New York.

I am able to add the reports of a few additional enses from this side of the Atlantie, hut from inquiries which I have made froin the hospital physieians of this eountry the condition appears to be extremely rare. Dr. George Ross, Professor of Clinieal Medicine in McGill University,

1 Iublia Juurn. Jled. Sclence, Slarel, IBH.

- Arohtres Cénemice, 1893.

3 Detutsches Archit fitr biln. Medicla, Bd. xL 1657.

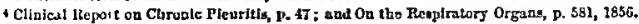

- Sew York Iledical Iecord, 1894. 
Montreal, has given an aecount of an extremely iateresting case, whieh closely simulated aneurism:

A man, aged thirty-seren years, was admitted to the General Hospital suffering from pain in the side, cough, and fever, which lasted nhout fve days, and which followed a serere wetting. There was deficient expnasion on the left side with duiness to the angle of the sespula and diminished fremitus. Within ten dass the expansive movemeat of the Ieft side beearae more impaired. The seeond and third intercostal spaees ia froat hecame prominent, presenting perceptible pulsation synehroaous with systole of the heart. About five days after the oaset of the illness he had a severe fit of eoughing, in whieh he hrought up, at lenst, a pint of pure pus, thiek, erenmy, and odorless. The cough eontinued for a ferr days, with expectoration of pus. The percusaion note on the len side heenme clearer and the pulsatiag tumor entirely disapneared. The temperature fell to noriaal and the ninn's strength returned. Ten weeks from the onset the man left the hospital strong and wcll.

Dr. F. P. Henry, of Philadelphia, ${ }^{7}$ reports a case from the Ipiseopal Hospital :

Woman, aged thirty years, admitted in the spring of 1880 . On the left side of the thorax there wero three strongly pulsating tumors-one about the size of lialf a lurge orange, in the left mammury region, directly orer the central portion of the heart; a seeond, much smaller and acuananted-i.e., with apex mueh stanller thas the base-wis situated on the left astero-inferior portion of the thorax; and a third, the largest of the three, oa the left posteroiaferior portion, its loag diameter, about four inches, correspoading with that of the vertehral eolumn. All these tumors possessed a stroag expansile, systolie pulsation. The day after admission pus was withdrawa hypodermically from the smaller tumor. The tumor orer the hen ft contained air, whieh was very evident on manipulation. Aspirntion was performed, nnd, some time after, a draiasge tuho wis inserted by Dr. Asthuryt. The womalt was removed by lier friends, but was alive a year after the operation.

Dr. Janeway, of New York, writes that he has met with oae ease of empsema of the left side, in which the tumor wos situated in the left seeond interspaee, whieh pulsatel wheu the putieat stood ereet, but whea the patient was lying down air fillel the sac.

These eases, with the thirty'eight eolleeted from literature by Comby and Kepler, make a total of forty-two eases. The condition is almost iavariably met with oa the left side. In oaly three instances, those of Kepler, Heyfelder," and Geigel, was the emipyema in the riglt side. Kepler thinks there may have beea a douht in Heyfelder's ease, but the report eeems perfectly elear. The tumor appeared between the seeond and third ribs oa the right side, aad pulsnted distinetly. It may possibly have beeu $n$ mediastinal abseess, as it was close to the pleural murgin. Only eight ounces of pus flowed out when puactured.

In the ease of Geigel, a maa, at. fifty-seven, had in the right manswary region a prominent projeetion which pulsated synebronously with the heart. The case terminated fatally. Between six and seven pounds of pus were fouad in the pleura.

I Caroule Yred. atd Surs- Journ., Yay, 1855.

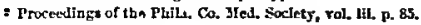

${ }^{3}$ Abstract by Kepler, 1.c. 
Empyema existed in all the cases, with the execption of one reported hy Kepler, from Eichhorst's clinic, in which the fluid was scrous. It oeeurred in a boy set. fourteen, who, fourteen days hefore his admission, had been seized with a severe pain on the right side, and shortly afterward great teuderness at the seventh rih. There wns dulness at the right base, whieh rapidly incrensed until it reached the angle of the seapula, and within a few days there were signs of effusion in the right thorax. On first examination the right side was enlarged, intereostal spaees promineat. There was active pulsation over the antero-lateral region of the right side of the chest reaching as high as the third rih, and synehronous with the movemeats of the heart. The apex-hent of the heart ras $1.5 \mathrm{~cm}$. above the nipple in the left mammary line. On aecount of suffoentive symptoms aspiration was performed and $800 \mathrm{e.em}$. of pure serous fluid removel. At a second puneture $200 \mathrm{e.} \mathrm{em.} \mathrm{more}$ were removed. Pulsation eensed after the vitidratral of the fluid. In fourteen dnys the luid renccumulated. An explontory puncture sboved it to be pus, and the operation for empyema was made. The seventh rib was reseeted and $300 \mathrm{c}$. em. of pus removed.

In only two instanees of Kepler's series was pyopneumotborax present. One reported by Fúréol,' a man set. twenty-two, had, in July, 1882, leftsided serous effusion, which was tnpped, and he reeovered. On Oetober 27 th there was agnin a large left side effusion witb nir. Tine bent was nt the right nipple, and about the end of November pulsation of the whole left side was noticed, synehronous with the henrt. It was most marked belind and in the axilln. The aspiration of 2 litres of pus nholished the pulsation. In Dillingham's case the man had pneumothomx.

To these eases must be ndded the one whieb I bere report, nnd the

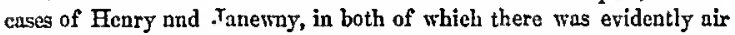
in the pleurn.

Two groups of eases may be reegnized: 1 , the intra-pleural pulsating pleurisy; 2, the pulsnting empyema neecsitatis, in whieh there is an externnl pulsating tumor. The latter condition, the most eommon, oceurred in twenty-five of the forty-two cnses, prohably also in a larger proportion, as there are several reports with very seanty details. The cxternal tumor is usually single, but in five cases there were two tumors, and in one, Dr. Henry's ease, three. The perforation of the pleurn usually oceurs in the anterior aspect of the chest, from the seeond to the sixth rib, sometimes elose to tlic sternum. In three cases the tumor appeared posteriorly - at the spine, at the angle of the seapula, and in the lumbar region. In the intra-pleural cases the pulsation is usually in the anterolateral region of the affeeted side, and may he evident on palpation only, or, as in the ease here reported, it rany be visible even at a distanee. 
Pulsating pleurisy usually oceurs in enses in which the fluid has existed for some time, but that it may occur in aeute eases, cven with a serous cxudation, is illustrated by Keplcr's patient. In Ross's case and in mine the condition was also acute.

Various explanations of the phenomenon have been offered. Dr. Broadbent ${ }^{2}$ suggests that it occurs when adhesions exist between the layers of the perienrdium nud between the pericardium and the chest wall. But that this cannot hold good in all cases is shown by reports of post-roortems in which such adhesions werc not present. Traube regarded destruction of the costal plcura, and marked paresis of the intercostal muscles as the conditions whicln rendered pleurisy possibie. In the case whieh I have reported, there was persistent tenderness of the thoracie walls, suggestive, to say the lenst, of involvement in an unusual degree of the parietal structures, but there was no oilema or speeial protuberanee of the spaces, and the condition came on too early to have been due to destruetive changes in the pleura. It was probably due to extreme distention of the sidc. Bourcret, in his recent monogmph on empyerua, holds that the pulsation is met with whenever the resistanee of the thoraeie wall is greatly reduced, as in the way Traube suggests, or when the resistanee out the part of the dinphragm is lieightened, as by the deposition of $n$ thick inycr of fibrin. The faet that the abstraction of $n$ very small quantity of fluid will at once abolish the pulsation, indientes that a eertain degree of pressure is a necessary condition. Comby thinks that the pulsation only oeeurs when the lung is compressed and adherent to the perieardium, so that the lieart movements are eommuniented through it to the pleural fluid, nnd so to the chest wall. Feréol makes n somewhat similar suggestion, holding that in every instance the condition is one of pneumothorax, in which nir forms an elastie eusbion betreen the perieardium and the fluid through which the pulsations of the heart are directly transnitted to the cliest wall.

The enses lane been mistaken for aneurism, and the situntion in which the pulsating cmpyema necessitatis usually devclops renders the error very pardonnble. The doubt ean readily be solved with a fine bypodernie needle.

The prognosis in pulsating pleurisy is not very farorable. Of the thirty-eight cases in Kepler's series, eeventeen died. But wc must remember thint most of these cases occurred before the days of safe and frequent operations upon the chest rall.

Complete eracuation of the fluid with free and permanent drainagc mects the indientions for trentment.

1 Lincet, 1884.

= Trati do I"eapyent, war L. Bouteret, Farit, $188 s$. 